Gontar, N.N. (2021). Features of budget planning in state and municipal administration in the Russian Federation. The Law and its Interpretation. Collection of Scientific Articles. European Scientific e-Journal, 5 (11), $37-$ 45. Hlučín-Bobrovníky: “Anisiia Tomanek” OSVČ.

Гонтарь, Н.Н. (2021). Особенности бюджетного планирования в государственном и муниципальном управлении в Российской Федерации. The Law and its Interpretation. Collection of Scientific Articles. European Scientific e-Journal, 5 (11), 37-45. Hlučín-Bobrovníky: “Anisiia Tomanek” OSVČ.

DOI: 10.47451 /jur2021-02-001

EOI: $10.11244 /$ jur2021-02-001

The paper is published in Crossref, Internet Archive, Google Scholar, Academic Resource Index ResearchBib, JGate, ISI, CiteFactor, ICI, eLibrary databases.

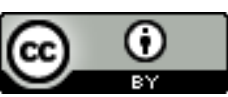

Nina N. Gontar

Associate Professor

Candidate of Sciences in Jurisprudence Department of State and Municipal Administration

North-West Institute of Management

The Russian Presidential Academy of National Economy and Public Administration

St Petersburg, Russia

E-mail: ninagontar@mail.ru

\title{
Features of budget planning in state and municipal administration in the Russian Federation
}

\section{Abstract:}

The author of the article examines the issues of budget planning in state and municipal administration. Attention is paid to the analysis of the correlation of its features and problems in the current economic crisis. It is concluded that the analyzed problems of budget planning form a new dynamic space of municipal management, which is aimed at constant adaptation to the changing and expanding regulatory field of public administration. This does not lead to minimizing the features of municipal management but to their constant increase in both volume and quantity. In the course of the study, comparative and historical methods of analysis were used. The materials of the article are intended for Russian and foreign specialists in the field of research of state and municipal planning on the territory of the Russian Federation.

\section{Keywords:}

budget planning, state and municipal management, local budget, revenues of municipal budgets, features of budget planning.

\section{Нина Никомаевна Гонтарь}

Аоцент, кандидат юридических наук КафеАра государственного и муниципального управления

Северо-Западный институт управления Российская Академия народного хозяйства и государственной служббы

Санкт-Петербург, Россия E-mail: ninagontar@mail.ru 


\title{
Особенности бюАжетного планирования в государственном и муниципальном управлении в Российской ФеАерации
}

\begin{abstract}
Aннотачия:
Автор статьи рассматривает вопросы бюджетного планирования в государственном и муниципальном управлении. Актуализируется внимание к анализу соотношения его особенностей и проблем в условиях текущего экономического кризиса. Аелается вывоА, что анализируемые проблемы бюджетного планирования формируют новое динамичное пространство муниципального менеджмента, которое направлено на постоянное аАаптирование к меняющемуся и Аополняющемуся регламентационному полю государственного управления. Это ведёт не к минимизации особенностей муниципального менеджмента, а к их постоянному увеличению как в объёмах, так и самом количестве. В ходе исследования применялись сравнительный и исторический методы анализа. Материалы статьи предназначены Аля российских и зарубежных специалистов в области исследования государственного и муниципального планирования на территории Российской Федерации.
\end{abstract}

Kлточевые слова:

бюджетное планирование, государственное и муниципальное управление, местный бюджет, Аоходы бюджетов муниципальных образований, особенности бюджетного планирования.

\section{Introduction}

Budget planning in state and municipal management is an important segment of the overall management of financial flows in any organization of this economic sector. As you know, the management of the local budget is based on the budget plan. The main function of budget planning is to formulate a goal and the tasks that follow from it.

Since budget planning is inextricably linked to the planning of the socioeconomic development of any municipality, both plans are directly interrelated. So, they are developed in parallel with each other and adopted simultaneously.

The main target areas of budget planning are:

1) forecasting the amount of financial resources required to support the planned activities;

2) forecasting the financial consequences of the implementation of plans and programs;

3) identify opportunities for implementing various measures within the local budget (Kovaleva, 2009).

In the context of the development of market principles of management, the functions of local authorities are expanding and becoming much more complex. The 
reforms are particularly focused on the lower level of the budget system because it is the budgets of municipalities that need to be given special attention. Management practice confirms that budget planning at the municipal level is the basis of financial support for the development of each Russian Federation's subject. Municipal budget funds are an important source of financial resources needed to address issues of local and regional importance. The level of subject socio-economic development is determined by the amount of the revenue part of the municipality budget, as well as the degree of its balance.

In the area of responsibility of local self-government there are several urgent and priority issues:

- economic and social development of the territory,

- investment attractiveness of the given territory,

- quality of life of the local population,

- infrastructure equipment of this municipality,

- environmental protection (Bykova, 2016).

It should take into account that the availability of their financial resources allows municipalities to independently:

- determine the main, priority areas;

- $\quad$ solve the problems specific to the given territory;

- accumulate funds for their intended use.

The general purpose of the research was to identify the features of budget planning in state and municipal administration in the Russian Federation at the current difficult stage of the country's development in the era of sanctions pressure.

Based on the goal, the following tasks were set:

- $\quad$ analyze the basic principles of the formation and execution of the local budget;

- identify and justify the main problems of budget planning.

To solve the tasks set, historical, comparative and logical research methods, which contributed to the objective analysis of the studied processes, were used.

The study used the European Charter of Local Self-Government, the Budget Code of the Russian Federation, as well as the work of Russian specialists in the field of budget planning in state and municipal administration N.N. Bykova, M.V. Bagrov, N.A. Istomina and others.

\section{Principles of formation and execution of the local budget}

According to the European Charter of Local Self-Government, the municipalities autonomy should be ensured not only by state support but also by the 
financial independence of local self-government bodies. The main part of the financial resources "should be supplemented by local taxes and fees, in respect of which municipalities have the right to set rates, benefits, and taxation procedures in the limits permitted by law" (European Charter of Local Self-Government, 1985).

With a fairly active process of transformation and development of budget planning in the Russian Federation, the issue of full provision of local selfgovernment bodies with financial resources that are necessary for the execution of an ever-increasing number of powers assigned to them remains practically unresolved, which is constantly emphasized by the heads of local government bodies. To solve fundamental and up-to-date issues of local significance, in compliance with numerous traditions, the executive and representative authorities of the municipality need significant financial resources.

As you know, it is the local budget that serves as the basis for fulfilling the expenditure obligations of the municipality. The rights and powers, assigned to local self-government bodies by the Budget Code of the Russian Federation, the Federal Law "On General Principles of the Organization of Local Self-Government in the Russian Federation", allow them to dispose of local financial resources (Bagrov, 2013). According to the Budget Code of the Russian Federation, a budget is a form of formation and expenditure of funds intended for financial support of the tasks and functions of the state and local self-government (Budget Code of the Russian Federation, 1998). In other words, the local budget is "a fund in which the financial resources of the municipality are concentrated, the formation, approval and execution, the control of the execution of which is carried out by the authorized bodies of local self-government" (Bagrov, 2013).

To clearly understand the nature and complexity of municipal budgeting, it is necessary to consider its main functions:

1) formation of funds of financial resources intended for financial support of the activities of local authorities. The financial resources of state and local government bodies consist mainly of tax and non-tax revenues, as well as gratuitous transfers (Gryaznova et al., 2012);

2) distribution and use of these funds among the branches of the national economy that relate to budget financing items;

3) control over the financial and economic activities of enterprises, organizations and institutions subordinate to these authorities (Kislitskaya, 2013).

It should take into account that the formation and execution of the local budget is based on clearly defined principles briefly defined in the article by N.N. Baranov:

- independence; 
- the completeness of the reflection of revenues, expenditures and sources of financing of budget deficits;

- balance;

- $\quad$ efficiency of the use of budget funds;

- $\quad$ total (aggregate) coverage of budget expenditures;

- $\quad$ transparency (openness) (Bykova, 2016).

Thus, according to the principle of independence of municipal budgets, local self-government bodies have the right to independently implement the budget process, bearing full responsibility for its implementation. The organization of the budget process makes it possible to identify possible ways and means to improve the management of state and municipal finances as much as possible. This is since the process is an integral element of all areas of financial and budgetary activities of government bodies at the state and municipal level. It should note that changes in the economic, social and financial policy of the state at a particular stage of the country's development significantly affect the budget process (Agayan et al., 2014).

\section{The main problems of budget planning}

The peculiarities of budget planning in state and municipal management give rise to the need to consider it following national trends. It makes the possibility to identify the main problems of budget planning at the level of the constituent entities of the Russian Federation.

1. The lack of sufficiently clear regulation of many aspects and issues of budget planning in federal laws and other legal acts, as well as private amendments to them. There is a rather urgent need to regulate the concepts, requirements, procedures and other elements of budget planning in national legal acts. The lack of such regulation leads to uncertainty in the functioning of budget planning. In 2013-2016, amendments were made to the Budget Code of the Russian Federation. Thanks to them, many important legal provisions in the field of budget planning were defined:

- the requirement for the regional budgets formation for three years is established;

- the need to develop long-term budget forecasts is fixed;

- the provisions that characterize the state programs of the subjects of the Russian Federation (previously long-term target programs of the Russian Federation's subjects) are detected (Istomina, 2015).

However, for the full development of budget planning in the regions, taking into account the tasks, it is necessary to introduce norms regulating the program 
classification of expenditures, which "should become the dominant budget classification if the government intends to increase the efficiency of expenditures based on the program budget" (Afanasyev et al., 2010).

2. There is an urgent need to introduce fundamental innovations defined by national conceptual documents and decisions into the planning practice (Istomina, 2015). The reform of budget planning in Russia has been in an active stage for about 13 years. Unfortunately, it is necessary to state that the introduction of budget planning new principles in different regions of the country goes in different directions.

3. The complexity of a reasonable and reliable calculation of the planned volumes of regional budget revenues in the context of instability of the national and regional economy in the context of the economic crisis caused by the cascade of sanctions applied to the Russian Federation over the past three years. This causes significant deviations in the actual indicators of regional budget revenues from the plan approved by the law on the budget of the subject of the Russian Federation. Several laws are passed during the year to amend the initial budget figures. According to A.I. Povarov "the poor quality of forecasts of the main budget parameters, the imperfection of the inter-budget policy violates the rhythm of the execution of the budgets of the subjects of the Russian Federation" (Povarova, 2013).

4. There is still insufficient experience in forecasting the need for public services in various types, which creates problems in designing planned justifications for budget allocations. The transition to planning based on the volume of state and municipal services and the determination of the standard cost of a service unit has determined the need to predict the need for the volume of services itself (Istomina, 2015).

5. The level of interaction between the state authorities of the regions and the divisions of the federal structures in the country subjects remains insufficient. It should also note that it remains difficult to obtain the necessary data for drawing up draft budgets. Researcher O.V. Kuznetsova notes the difficulty in achieving the task of effective interaction between the federal centre and the subjects of the Federation (Kuznetsova, 2010). This problem mainly concerns the interaction between regional financial authorities and divisions of the Federal Tax Service of Russia.

6. Objectively different levels of development of budget planning in the regional municipalities, including heterogeneous personnel composition and professional activities experience of municipal administrations' specialists. For planning regional and local budgets, the traditional practice is the interaction of 
regional executive authorities with local self-government bodies. At this level, the problem of personnel training arises.

7. The actual imbalance of interests of regional financial authorities and economic entities whose activities provide tax revenues to the regional budget (Istomina, 2015).

Thus, these problems of budget planning form a new dynamic space of municipal management, which is aimed at constant adaptation to the changing and expanding regulatory field of public administration. This does not lead to minimizing the features of municipal management but their constant increase both in volume and in quantity.

\section{Discussion}

The study of the main problems of budget planning in the Russian Federation identifies issues that can be investigated not only in the national field of jurisprudence but also at the international level:

- What innovative methods and tools can be used to improve public budget planning?

- What legal basis should be created for the effective implementation of forecasting the demand for services as part of their planning?

- What is the set of legal documents that can solve the actual imbalance between the interests of the regional financial authorities and economic entities which provide income tax revenues in the regional budget?

The solution to these issues in countries with a similar legal system will help you to simulate the way out of the crisis not only in the economic and legal system of the Russian Federation but also in many countries that are experiencing similar problems.

\section{Conclusion}

It was confirmed in the study course that the issue of full provision of local selfgovernment bodies with financial resources that are necessary for the implementation of an ever-increasing number of powers assigned to them remains, unresolved with a fairly active process of transformation and development of budget planning in the Russian Federation. To solve fundamental and up-to-date issues of local significance in compliance with numerous traditions, the executive and representative authorities of the municipality need significant financial resources. 
The organization of the budget process makes it possible to identify possible ways and means to improve the management of state and municipal finances as much as possible. This is since this process is an integral element of all areas of financial and budgetary activities of government bodies at the state and municipal level.

However, despite the apparent external paradox, the problems of budget planning form a new dynamic space of municipal management, which is aimed at constant adaptation to the changing and expanding regulatory field of public administration. This does not lead to minimizing the municipal management features but to their constant increase both in volume and in quantity.

Thus, the analysis of budget planning features in the state and municipal administration in the conditions of the ending but, at the moment, the continuing economic crisis is one of the most important areas of the work of economists and researchers.

\section{References:}

Afanasyev, M.P. et al. (2010). Program budget: goals, classification, and design principles. Financial Journal, 3, 5-18. Moscow: Research Financial Institute. (in Russian)

Agayan, S.A. et al. (2014). Actual problems of formation of the revenue part of municipal budgets. Management of Economic Systems: Electronic scientific journal, 3 (63), 2-14. (in Russian)

Bagrov, M.V. (2013). Municipal budget: concept and functions, analysis of the structure and features of the budget process. Fundamentals of Economics, Management and Law, 6 (12), 8-13. (in Russian)

Budget Code of the Russian Federation. No 145-FL. (1998, July 31). Ed. in 2016, November 30. Retrieved December 11, 2020, from http://base.consultant.ru (in Russian)

Bykova, N.N. (2016). Features of planning and execution of the municipal budget. Young Scientist, 28, 366-368. (in Russian)

European Charter of Local Self-Government. No 122. (1985, October 15). Retrieved December 12, 2020, from https://www.coe.int/en/web/conventions/fulllist/-/conventions/rms/090000168007a105 (in Russian)

Gryaznova, A.G. et al. (2012). Finance: textbook. 2nd ed. Moscow: Finance and Statistics. (in Russian) 
Istomina, N. A. (2015). Typical problems of budget planning in the subject of the Federation: characteristics and consequences. Bulletin of the South Ural State University. Series "Economics and Management", 2, 9, 50-57. (in Russian)

Kovaleva, T.I. (2009). Budget policy and budget planning in the Russian Federation. Moscow: KnoRus. (in Russian)

Kislitskaya, N.A. (2013). Formation and development of the financial and budgetary base of municipalities (on the example of Rostov-On-Don). Management of Economic Systems: Electronic Scientific Journal, 50 (2), 1-17. (in Russian)

Kuznetsova, O.V. (2010). Regional budgets and inter-budgetary relations in the context of the crisis. Regional Studies, 2 (28), 32-41. (in Russian)

Povarova, A.I. (2013). Regional budgets-2014: problems of formation and implementation. Problems of Territory Development, 1 (75), 45-56. (in Russian) 